\title{
Role of genetic polymorphisms of the RNASEL gene on familial prostate cancer risk in a Japanese population
}

\author{
H Nakazato', K Suzuki',', H Matsui', N Ohtake', S Nakata' and H Yamanaka' \\ 'Department of Urology, Gunma University School of Medicine, 3-39-22, Showa-machi, Maebashi, Gunma, 37 I 85 I I, Japan
}

The RNASEL gene on chromosome Iq25 has been identified as a prostate cancer susceptibility gene. We screened for RNASEL germline mutations in familial prostate cancer patients, and performed a case-control study to examine the association of specific variants with prostate cancer risk in the Japanese. Three variants within the RNASEL gene, G282A, GI385A and TI623G were identified. GI385 and TI623G variants result in previously reported Arg462Gln and Asp54IGlu variants, respectively. The novel G282A variant does not cause amino-acid substitution. A case-control study consisting of I0 I familial prostate cancer cases and 105 noncancer controls showed that the $\mathrm{G} / \mathrm{l} / \mathrm{G} \ln$ genotype of codon 462 was observed in $7.6 \%$ of controls. However, the Gln/Gln genotype was not observed in cases, and reduced prostate cancer risk (odds ratio $(O R)=0.061, P=0.014$ ). The Asp/Asp genotype of codon54I increased the familial prostate cancer risk $(O R=7.37, P=0.0004)$. In subset analysis, a significant association was observed in patients with more than two affected members ( $O R=3.15, P=0.028)$, and weak associations were found in patients with metastatic disease $(O R=2.40, P=0.11)$ and high-grade disease (Gleason score $\geqslant 7)(O R=3.07, P=0.14)$. These findings suggested that the polymorphic changes within the RNASEL gene may be associated with familial prostate cancer risk in a Japanese population.

British Journal of Cancer (2003) 89, 69I-696. doi: 10.1038/sj.bjc.660 I 075 www.bjcancer.com

(c) 2003 Cancer Research UK

Keywords: RNASEL gene; familial prostate cancer; Japanese population

Familial clustering of prostate cancer has been studied due to its clinical significance as a high-risk group of prostate cancer (Carter et al, 1992, 1993) and its genetic significance as a biological model to identify susceptibility genes (Berthon et al, 1998; Berry et al, 2000; Bratt, 2000, 2002). Six prostate cancer susceptibility loci (HPC1 at 1q24-25 (Smith et al, 1996), PCAP at 1q42-43 (Berthon et al, 1998), HPCX at Xq27-28 (Xu et al, 1998), CAPB at $1 \mathrm{p} 36$ (Gibbs et al, 1999), HPC20 at 20q13 (Berry et al, 2000) and HPC2 at 17p12 (Tavtigian et al, 2001)) and two candidate susceptibility genes (HPC2/ELAC2 at $17 \mathrm{q}$ (Tavtigian et al, 2001) and RNASEL at 1q24-25 (Carpten et al, 2002)) have been reported.

RNASEL was recently identified, and germline mutations were cosegregated within families with prostate cancer linked to the HPC1 region, at 1q24-25 (Carpten et al, 2002). In Finnish patients, the truncation mutation at base pair position 793 (Glu265 $\rightarrow$ stop) was associated with hereditary prostate cancer (Rökman et al, 2002). Wang et al (2002) reported the association of the Arg462Gln genotype with familial prostate cancer risk in a United States population. RNASEL encodes the $2^{\prime}, 5^{\prime}$-oligoisoadenylate-synthetase-dependent ribonuclease L protein (Zhou et al, 1993), and is involved in the interferon-regulated 2-5A system that regulates cell proliferation and apoptosis (Hassel et al, 1993; Castelli et al, 1998).

The incidence of prostate cancer was much lower in Japan in comparison with the Western countries (Nakata et al, 1996). However, it has been increasing annually, and the understanding of the pathophysiology of this disease is warranted in Japan.

*Correspondence: Dr K Suzuki, E-mail: kazu@showa.gunma-u.ac.jp Received 29 January 2003; revised 25 April 2003; accepted 30 April 2003
Although, the frequency of familial/hereditary prostate cancer pedigrees is lower than that in Western countries (Ohtake et al, 1998; Ohtake et al, 2002), information on genetic characteristics of Japanese familial/hereditary prostate cancer would be interesting from the viewpoint of ethnic differences. In the present study, we analysed RNASEL germline mutations in familial prostate cancer in Japan, and investigated the significance of the RNASEL gene in genetic susceptibility in a Japanese population.

\section{MATERIALS AND METHODS}

\section{Patients}

The present study included 101 prostate cancer patients with a family history of prostate cancer. The numbers of affected family members were two out of 72 patients, three out of 14 patients and four out of 15 patients. In all, 29 patients with three or more affected family members were categorised into hereditary prostate cancer according to Carter's criteria (Carter et al, 1993). Prostate cancer was confirmed histologically at Gunma University Hospital and its affiliated hospitals. Ages ranged from 40 to 88 years with a mean age of 70.0 years. Clinical stages were A in 2, B in 41, C in 32, $\mathrm{D}$ in 24 and unknown in two patients according to Jewett's staging system. Gleason scores were less than 7 in 25 and equal or greater than 7 in 76 patients. Controls were recruited from outpatient clinics at Gunma University Hospital. Controls were excluded if they had an abnormal PSA level (i.e. $>4.0 \mathrm{ng} \mathrm{ml}^{-1}$ ), and abnormal digital rectal examination, and a previous diagnosis of cancer. Ages ranged from 51 to 88 years with a mean of 71.2 years. No 
significant differences in age were observed between cases and controls. The Ethical Committee of Gunma University approved this study, and all participants were enrolled under informed consent.

\section{Single-strand conformation polymorphism (SSCP) and direct sequencing}

Mutations in the coding sequence of six exons of the RNASEL gene in familial prostate cancer patients were screened by the SSCP method. The sequences for the PCR primers covering the coding sequence for six exons were provided by Dr Carpten (the National Human Genome Research Institute, National Institutes of Health). Genomic DNA was isolated from whole blood using a GENOMIX kit (Talent srl. Treisete, Italy). Samples were diluted to $10 \mu \mathrm{g} \mu \mathrm{l}^{-1}$ and stored at $-20^{\circ} \mathrm{C}$. PCR reactions were performed in a total $25 \mu \mathrm{g}$ reaction volume containing $20 \mathrm{ng}$ of genomic DNA, primers $(10 \mu \mathrm{M}$ of each forward and reverse primers), $1 \times$ PCR buffer (1.5 mM MgCl, $10 \mathrm{~mm}$ Tris ( $\mathrm{pH} 9.0), 50 \mathrm{~mm} \mathrm{KCl}$ and $0.1 \%$ Triton X$100)$, dNTPs (20 mM), and $1 \mathrm{U}$ of AmpliTaq Gold polymerase (PE Applied Biosystems, Foster City, CA, USA). The PCR primer amplification was performed in a GeneAmp ${ }^{\circledR} 9700$ thermalcycler (PE Applied Biosystems). Cycling conditions were $95^{\circ} \mathrm{C}$ for $10 \mathrm{~min}$ for one cycle; $94^{\circ} \mathrm{C}$ for $30 \mathrm{~s}, 60^{\circ} \mathrm{C}$ for $30 \mathrm{~s}, 72^{\circ} \mathrm{C}$ for $30 \mathrm{~s}$ for 35 cycle; followed by an elongation cycle of $72^{\circ} \mathrm{C}$ for $10 \mathrm{~min}$. PCR products ( $3 \mu \mathrm{l}$ ) were mixed with $7 \mu \mathrm{l}$ of denaturing solution (formamide with $10 \mathrm{~mm} \mathrm{NaOH}$ ), were incubated at $95^{\circ} \mathrm{C}$ for $5 \mathrm{~min}$, and were chilled on ice immediately. Samples were electrophoresed at $6 \mathrm{~V} \mathrm{~cm}^{-1}$ for $15 \mathrm{~h}$ at $4{ }^{\circ} \mathrm{C}$ in $\mathrm{GMA}^{\mathrm{TM}}$ (gene mutation analysis) Gels in $30 \mathrm{~mm}$ Trisacetate EDTA (Elchrom Scientific AG, Switzerland). After electrophoresis, gels were stained with cyber-gold, and were visualised under UV irradiation. To confirm the accuracy of bands detected by the SSCP method, at least two PCR products were selected, and were sequenced using an automated ABI Prism 310 Genetic Analyzer (PE Applied Biosystems) according to the instructions of the manufacturer. To facilitate the genotyping of Arg462Gln and Asp541Glu polymorphisms of the RNASEL gene, we designed primers covering these polymorphic sites. The sequences of primers for Arg462Gln were $5^{\prime}$-cac agc ggg aag tct ctt gt- $3^{\prime}$ (GenBank accession number NM_021133; nt 1202-1221); forward, and $5^{\prime}$-ggt ggg tgt atc cac agg ac-3' (GenBank accession number NM_021133; nt 1450-1431); reverse. Those for Asp541Glu were $5^{\prime}$ ccttgagattcctcccatca-3' (GenBank accession number AL138776; nt 88952-88933); forward, and 5'-ccaggatggaagagacgatg-3' (GenBank accession number AL138776; nt 88701-88720); reverse.

\section{Statistical analysis}

The $\chi^{2}$ test was performed to evaluate whether the distribution of genotype frequency of Arg462Gln and Asp541Glu polymorphisms of the RNASEL gene varied among cases and controls. Odds ratios (ORs) were calculated as an estimate of relative risk, and $95 \%$ confidence intervals (CIs) were calculated from unconditional logistic regression models. Genotypes were compared between cases and controls. We also performed logistic regression analysis whether clinical stage, pathological grade, age and number of affected family members were associated with RNASEL genotypes. The categories of clinical stage were localised (stages A-C) or metastatic (stage D), and that of pathological grade was Gleason score $<7$ or $\geqslant 7$. Ages were divided into $<70$ or $\geqslant 70$ years. The SPSS Professional Statistics ${ }^{\mathrm{TM}}$ (SPSS inc., Chicago, IL, USA) was used for all statistical analyses.

\section{RESULTS}

Mutation screening of the coding sequence of six exons showed one altered band in PCR product amplified by the primer set-1a. 2

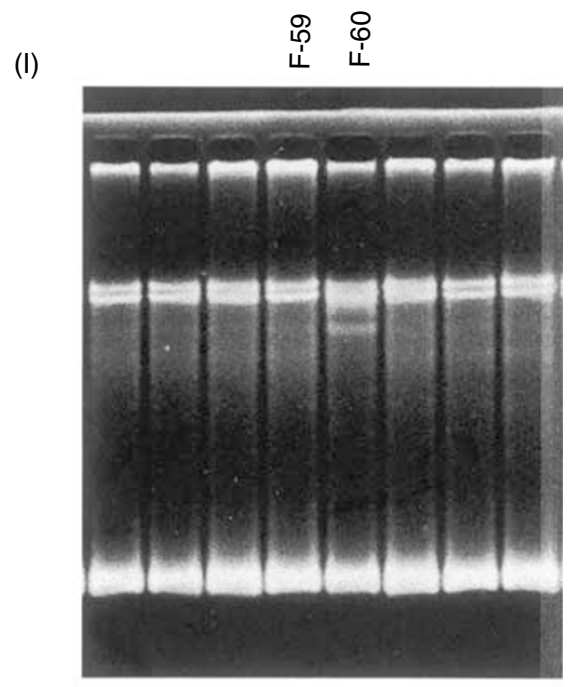

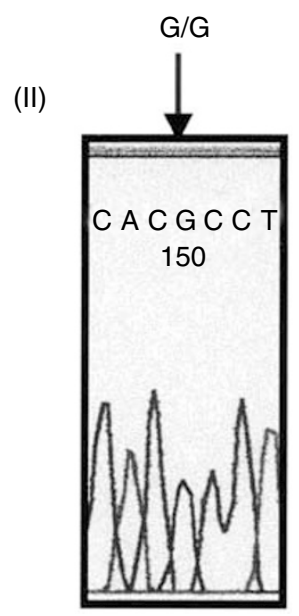

F-59

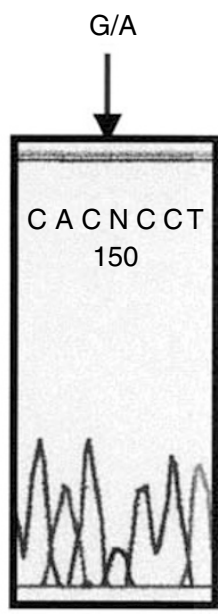

F-60
Figure I Detection of G282A mutation of the RNASEL gene. (I) An aberrant pattern of SSCP was observed in F-60. The pattern of F-59, the affected brother of F-60, was normal. (II) Direct sequencing showed G/A heterozygous pattern of G282A in F-60. Wild-type G/G genotype was observed in F-59.

(GenBank accession number NM_021133, nt 105-419), several patterns in the primer set-1d (GenBank accession number AL138776, nt 92278-91873) and the primer set-3 (GenBank accession number AL138776, nt 88897-88565) (Table 1). Direct sequencing revealed the $G \rightarrow A$ transition at base pair position 282 (Figure 1). In this patient, this transition caused no amino-acid substitution (acg: Thr $\rightarrow$ aca:Thr). We performed three independent PCR reactions and direct sequencing and confirmed the G282A mutation. This patient was 64 years old at diagnosis of

Table I Analysis of the RNASEL gene is patients with familial prostate cancer in Japan

\begin{tabular}{lcll}
\hline Exon & Codon & Nucleotide change & Amino-acid change \\
\hline 2 & 94 & G282A & None \\
2 & 462 & Gl385A & Arg $\rightarrow$ Gln \\
4 & 541 & Gl623T & Asp $\rightarrow$ Glu \\
\hline
\end{tabular}


prostate cancer, and had stage B disease and a Gleason score of seven. No mutation was found in the affected brother (71 years at diagnosis, stage $\mathrm{C}$, Gleason score 6) of this patient and controls at base pair position 282 .

Direct sequencing of the primer set-1d and the primer set-3 showed Arg462Gln and Asp541Glu polymorphic sites, respectively (Figures 2 and 3). In controls, Arg/Arg, Arg/Gln and Gln/Gln genotypes were found in $71(67.6 \%), 26(24.8 \%)$ and $8(7.6 \%)$, respectively (Table 2 ). In familial prostate cancer cases, Arg/Arg and Arg/Gln genotypes were found in $69(68.3 \%)$ and $32(31.7 \%)$, respectively. No Gln/Gln genotype was found in any cases, and this genotype tended to reduce prostate cancer risk $(\mathrm{OR}=0.0061,95 \%$ $\mathrm{CI}=0.035-0.11, P=0.014)$. Regarding the Asp541Glu genotype, Glu/Glu, Glu/Asp and Asp/Asp genotypes were found in 59
(I)

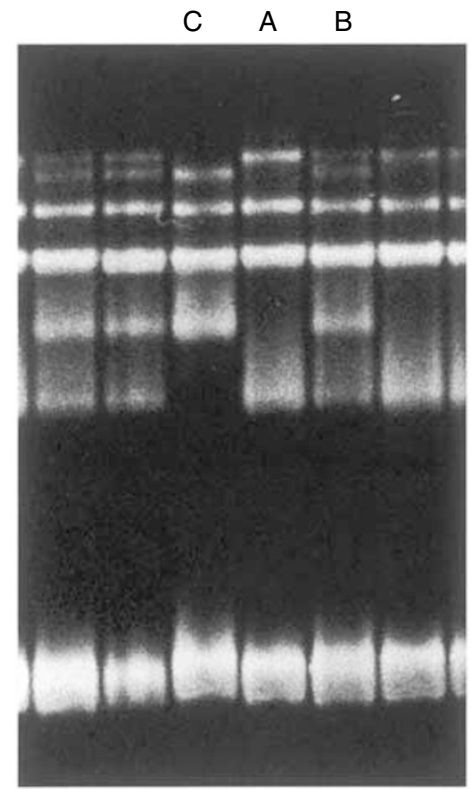

(II)

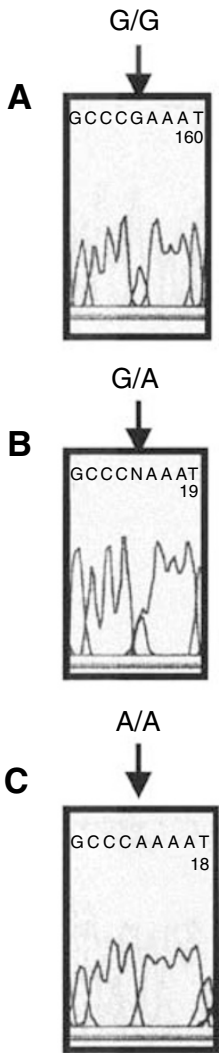

Figure 2 Detection of GI385A mutation of the RNASEL gene. (I) Three patterns were observed by SSCP analysis $(\mathbf{A}-\mathbf{C})$. (II) Direct sequencing showed $G / G, G / A$ and $A / A$ corresponding to $A, B$ and $C$, respectively.
(56.2\%), $43(41.0 \%)$ and three (2.9\%) in controls, respectively. In cases, Glu/Glu, Glu/Asp and Asp/Asp genotypes were found in 51 $(50.5 \%), 32(31.7 \%)$ and $18(17.8 \%)$, respectively. The Asp/Asp genotype increased prostate cancer risk to a significant degree $(\mathrm{OR}=6.94,95 \% \mathrm{CI}=3.98-12.10, P=0.0009$, in comparison with the Glu/Glu genotype; $\mathrm{OR}=7.37,95 \% \mathrm{CI}=4.23-12.86, P=0.0004$, in comparison with Glu/Glu + Glu/Asp genotypes).

Stratification of cases according to clinical stage and pathological grade was performed (Tables 3 and 4). Although no significant differences were observed in the Arg462Gln genotype in the clinical stage, the Asp/Asp genotype of codon541 tended to be frequently observed in patients with metastatic disease
(I)

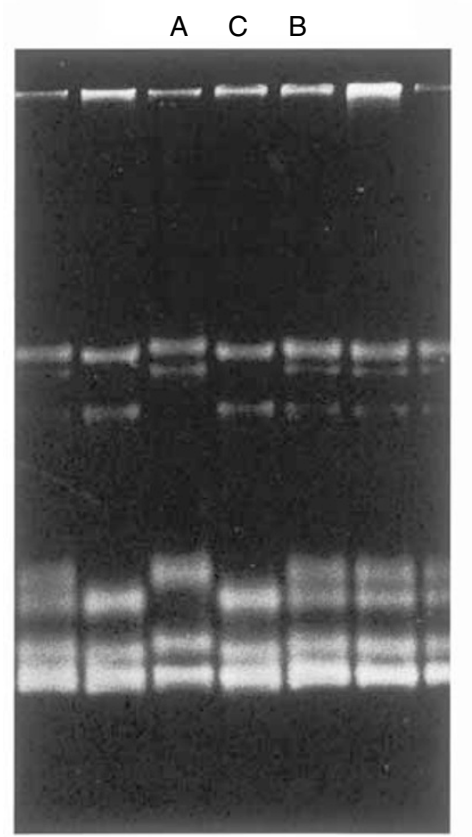

(II)

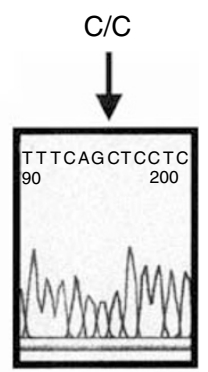

B

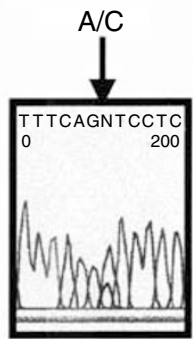

$\mathrm{A} / \mathrm{A}$

C

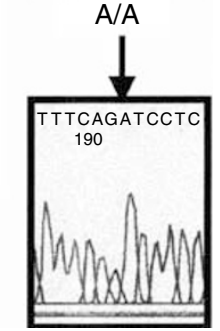

Figure 3 Detection of GI623 T mutation of the RNASEL gene. (I) Three patterns were observed in the analysis (A-C). (II) Direct sequencing showed $\mathrm{C} / \mathrm{C}, \mathrm{C} / \mathrm{A}$ and $\mathrm{A} / \mathrm{A}$ corresponding to $\mathbf{A}, \mathbf{B}$ and $\mathbf{C}$, respectively. Note that the sequences appearing in the figures are reverse complement due to using the reverse primer for sequencing.

Table 2 Association of Arg462Gln and Asp462Gln genotypes of RNASEL with prostate cancer risk

\begin{tabular}{lcclll}
\hline & \multicolumn{2}{c}{ No. of subjects (\%) } & & \\
\cline { 2 - 3 } Genotype & Case & Control & & OR (95\% CI) & P-value \\
\hline Arg462Gln & & & & \\
Arg/Arg & $69(68.3 \%)$ & $71(67.6 \%)$ & $1.0($ Ref.) & \\
Arg/Gln & $32(31.7 \%)$ & $26(24.8 \%)$ & $1.27(0.73-2.21)$ & 0.45 \\
Gln/Gln & $0(0.0 \%)$ & $8(7.6 \%)$ & $0.061(0.035-0.11)$ & 0.014 \\
Asp54IGlu & & & & \\
Glu/Glu & $51(50.5 \%)$ & $59(56.2 \%)$ & $1.0($ Ref.) & 0.62 \\
Glu/Asp & $32(31.7 \%)$ & $43(41.0 \%)$ & $0.86(0.49-1.50)$ & 0.0009 \\
Asp/Asp & $18(17.8 \%)$ & $3(2.9 \%)$ & $6.94(3.98-12.10)$ & \\
Glu/Glu+Glu/Asp & $83(82.2 \%)$ & $102(97.1 \%)$ & $1.0($ Ref.) & 0.0004 \\
Asp/Asp & $18(17.8 \%)$ & $3(2.9 \%)$ & $7.37(4.23-12.86)$ & \\
\hline
\end{tabular}


Table 3 Relation between Arg462GIn and Asp54IGlu genotypes and pathological grade

\begin{tabular}{|c|c|c|c|c|}
\hline \multirow[b]{3}{*}{ Genotype } & \multirow{2}{*}{\multicolumn{2}{|c|}{$\begin{array}{c}\text { No. of subjects (\%) } \\
\text { Gleason score }\end{array}$}} & \multirow[b]{3}{*}{ OR $(95 \% \mathrm{Cl})$} & \multirow[b]{3}{*}{$P$-value } \\
\hline & & & & \\
\hline & $<7$ & $\geqslant 7$ & & \\
\hline \multicolumn{5}{|l|}{$\operatorname{Arg} 462 \mathrm{Gln}$} \\
\hline Arg/Arg & $19(76.0 \%)$ & $50(65.8 \%)$ & I.0 (Ref.) & \\
\hline $\mathrm{Arg} / \mathrm{Gln}$ & $6(24.0 \%)$ & $26(34.2 \%)$ & $1.65(0.94-2.87)$ & 0.69 \\
\hline $\mathrm{Gln} / \mathrm{Gln}$ & $0(0.0 \%)$ & $0(0.0 \%)$ & & \\
\hline \multicolumn{5}{|l|}{ Asp54 I Glu } \\
\hline Glu/Glu & $14(56.0 \%)$ & 37 (48.7\%) & I.0 (Ref.) & \\
\hline Glu/Asp & $9(36.0 \%)$ & $23(30.3 \%)$ & $0.97(0.55-1.69)$ & 0.95 \\
\hline Asp/Asp & $2(8.0 \%)$ & $16(21.1 \%)$ & $3.03(1.74-5.28)$ & 0.16 \\
\hline Glu/Glu+Glu/Asp & $23(92.0 \%)$ & $60(78.9 \%)$ & I.0 (Ref.) & \\
\hline Asp/Asp & $2(8.0 \%)$ & $16(21.1 \%)$ & $3.07(1.76-5.35)$ & 0.14 \\
\hline
\end{tabular}

Table 4 Relation between Arg462Gln and Asp54IGlu genotypes and clinical stage of prostate cancer

\begin{tabular}{|c|c|c|c|c|}
\hline \multirow[b]{2}{*}{ Genotype } & \multicolumn{2}{|c|}{ No. of subjects (\%) } & \multirow[b]{2}{*}{ OR $(95 \% \mathrm{Cl})$} & \multirow[b]{2}{*}{$P$-value } \\
\hline & Localised & Metastatic & & \\
\hline $\operatorname{Arg} 462 \mathrm{Gln}$ & $5 \mid(68 . \%)$ & & & \\
\hline Arg/Arg & 24 (32.0\%) & 17 (70.8\%) & I.0 (Ref.) & \\
\hline Arg/Gln & $0(0.0 \%)$ & $7(29.2 \%))$ & $0.88(0.50-1.53)$ & 0.79 \\
\hline $\mathrm{Gln} / \mathrm{G} \ln$ & & $0(0.0 \%)$ & & \\
\hline \multicolumn{5}{|l|}{ Asp54IGlu } \\
\hline Glu/Glu & 39 (52.0\%) & $12(50.0 \%)$ & I.0 (Ref.) & \\
\hline Glu/Asp & 25 (33.3\%) & $5(20.8 \%)$ & $0.65(0.37-1.13)$ & 0.46 \\
\hline Asp/Asp & II (I4.7\%) & $7(29.2 \%)$ & $2.07(1.19-3.61))$ & 0.21 \\
\hline Glu/Glu+Glu/Asp & $64(85.3 \%)$ & 17 (70.8\%) & I.0 (Ref.) & \\
\hline Asp/Asp & $11(14.7 \%)$ & 7 (29.2\%) & $2.40(1.37-4.18)$ & 0.11 \\
\hline
\end{tabular}

Two cases were excluded due to lack of staging information.

Table 5 Relation between Arg462GIn and Asp54IGlu gennotypes and the number of affected family members

\begin{tabular}{|c|c|c|c|c|}
\hline \multirow[b]{3}{*}{ Genotype } & \multicolumn{2}{|c|}{ No. of subjects (\%) } & \multirow[b]{3}{*}{ OR (95\% Cl) } & \multirow[b]{3}{*}{$P$-value } \\
\hline & \multicolumn{2}{|c|}{ No. of affected members } & & \\
\hline & 2 & $>2$ & & \\
\hline \multicolumn{5}{|l|}{ Arg462Gln } \\
\hline Arg/Arg & 49 (68.1\%) & $20(69.0 \%)$ & I.0 (Ref.) & \\
\hline $\mathrm{Arg} / \mathrm{Gln}$ & 23 (31.9\%) & $9(31.0 \%)$ & $0.96(0.55-1.67)$ & 0.93 \\
\hline $\mathrm{Gln} / \mathrm{Gln}$ & $0(0.0 \%)$ & $0(0.0 \%)$ & & \\
\hline \multicolumn{5}{|l|}{ Asp54IGlu } \\
\hline Glu/Glu & 37 (51.4\%) & 14 (48.3\%) & I.0 (Ref.) & \\
\hline Glu/Asp & $26(36.1 \%)$ & $6(20.7 \%)$ & $0.61(0.35-1.06)$ & 0.37 \\
\hline Asp/Asp & $9(12.5 \%)$ & $9(31.0 \%)$ & $2.64(\mid .52-4.61)$ & 0.08 \\
\hline Glu/Glu+Glu/Asp & 63 (87.5\%) & 20 (69.0\%) & I.0 (Ref.) & \\
\hline Asp/Asp & $9(12.5 \%)$ & 9 (31.0\%) & $3.15(1.81-5.49)$ & 0.028 \\
\hline
\end{tabular}

$(\mathrm{OR}=2.40,95 \% \mathrm{CI}=1.37-4.18, P=0.11$, in comparison with Glu/ Glu + Glu/Asp genotypes) (Table 3). As for pathological grade, no significant tendency was observed in the Arg462Gln genotype, however, the Asp/Asp genotype of codon541 tended to be frequently seen in patients with high-grade prostate cancer $(\mathrm{OR}=3.07,95 \% \mathrm{CI}=1.76-5.35, P=0.14$, in reference with $\mathrm{Glu} /$ Glu + Glu/Asp genotypes) (Table 4). Stratification of subjects according to age showed a similar tendency of distribution of both the genotypes as demonstrated in Table 4 (data not shown). The frequency of the Asp/Asp genotype of codon541 was significantly higher in families with more than two affected members compared with that in families with two affected members $(\mathrm{OR}=3.15,95 \%$ $\mathrm{CI}=1.81-5.49, P=0.028$, in comparison with $\mathrm{Glu} / \mathrm{Glu}+\mathrm{Glu} / \mathrm{Asp}$ genotypes) (Table 5). 


\section{DISCUSSION}

In the present study, we identified three variants within the RNASEL gene among 101 patients with familial prostate cancer. Two of them were previously reported variants, Arg461Gln and Asp541Glu. We found one novel mutation of G-A transition at codon94. This mutation does not cause amino-acid substitution, and was not observed in the affected brother of the case. Truncating mutation E265X was reported to cosegregate in highrisk US families with hereditary prostate cancer (Carpten et al, 2002). E265X was also associated with hereditary prostate cancer in Finnish patients (Rökman et al, 2002). In the present study, E265X mutation was not observed in cases and controls. Rennert et al (2002) found a novel founder mutation, 471delAAAG, in Ashkenazi Jews, and reported that this mutation was associated with prostate cancer risk in Ashkenazi men. In the present study, this mutation was not observed in patients with familial prostate cancer in Japan.

The most significant finding in the present study was the association of the Asp541Glu genotype with prostate cancer risk. In the Japanese population, the frequency of the wild-type Asp/Asp genotype was rare (2.9\% in controls), and the Glu541 variants were prevalent in controls. We calculated ORs of Glu/Asp and Asp/Asp genotypes in comparison with the Glu/Glu genotype as shown in Table 2. The Asp/Asp genotype was significantly associated with familial prostate cancer risk $(P=0.0004)$, with $\mathrm{OR}=7.37$. Furthermore, subset analysis showed that this significant association was observed with more than two affected family members, that is, hereditary prostate cancer $(\mathrm{OR}=3.15, P=0.028)$, and a weak association was observed with metastatic stage disease $(\mathrm{OR}=2.40$, $P=0.11)$ and high-grade (Gleason score $\geqslant 7) \quad(\mathrm{OR}=3.07$, $P=0.14)$. These associations have not been reported by any other studies (Casey et al, 2002; Rökman et al, 2002; Wang et al, 2002), and might be a specific feature of familial prostate cancer in Japan.

Another significant finding was the low frequency of the Gln 462 variant in patients with familial prostate cancer. In the present study, we did not find the Gln/Gln genotype in patients with familial prostate cancer. The present findings supported the results reported by Wang et al (2002). They observed that the low frequency of the Gln 462 genotype was significantly associated with familial prostate cancer. Subset analysis showed that this association was observed in the younger group, localised stage group and low-grade disease. However, we did not find any significant differences in the frequencies of Arg/Arg and Arg/Gln genotypes in subset analysis. On the other hand, Rökman et al (2002) reported a higher, but not significant frequency, of the Gln462 variant. Recently, Casey et al (2002) reported that the Gln462 variant has three times less enzymatic activity than the wild type. They found that the $G \ln 462$ variant is significantly associated with prostate cancer risk. Controls in Casey's study were nonaffected brothers, however, those in other studies including the present study were population-based controls (Rökman et al, 2002 ; Wang et al, 2002). However, the exact reasons for discrepancies between these results are unknown. Further studies will be necessary to confirm the significance of the Arg462Gln genotype in the risk of familial prostate cancer.

Limitations of the present study are the relatively small sample number and the inclusion criteria of familial prostate cancer. We started to collect familial prostate cancer pedigrees in 1994 (Ohtake et al, 1998), and the frequency of familial prostate cancer was about 3\% (Ohtake et al, 2002). The incidence of prostate cancer in Japan is markedly lower than those in Western countries (Nakata et al, 1996), and the national awareness of prostate cancer has increased only in these two decades. These situations have made it difficult to diagnose prostate cancer at an early age, to identify affected members in equal or more than three generations and three members in one family. Due to these reasons, we enrolled prostate cancer patients from at least two affected members in families. The present study design used did not involve prospective recruitment of study subjects into a study cohort. This point is another limitation of the present study, and it could cause several biases.

In summary, we found three variants within the RNASEL gene, G282A, G1385A and T1623G. The G1385 and G1623 T variants result in previously reported Arg462Gln and Asp541Glu variants, respectively. The G282A variant does not cause amino acid substitution, and this mutation was identified for the first time. A case-control study showed that the Gln/Gln genotype of codon 462 was not observed in cases, and reduced prostate cancer risk to a significant degree. The Asp541Glu genotype had a marked association with familial prostate cancer risk. The Asp/Asp genotype increased the familial prostate cancer risk, and was associated with risk of patients with many affected family members. These associations need further large-scale and prospective studies to confirm the consequences of the RNASEL gene on familial prostate cancer.

\section{ACKNOWLEDGEMENTS}

The present work was supported by Grant-in-Aid from the Ministry of Education, Science, Sports and Culture of Japan (Project Nos. 13877264 and 14370503).

We thank the following doctors for registration of familial prostate cancer patients in this study: Takanori Suzuki, Hirotomo Takahashi, Yotsuo Higashi, Takeo Makino, Isao Kurosawa, Hisanori Yajima, Jun Kuribara, Kazuhisa Saruki, Kazuhiko Okabe, Koichi Kitaura, Yoshimi Tamura, Tetsuo Sekihara, Nobuo Kato, Kazunori Ebihara, Hideo Kiren, Yoshio Ichinose, Susumu Jinbo, Tadatoshi Shinozaki, Masaya Miki, Mikio Kobayashi, Hiroyuki Jinbo and Kiyotaka Tsuchiya. We thank Naomi Takase for excellent technical support.

\section{REFERENCES}

Berry R, Schroeder JJ, French AJ, McDonnell SK, Peterson BJ, Cunningham JM, Thibodeau SN, Schaid DJ (2000) Evidence for prostate cancersusceptibility locus on chromosome 20. Am J Hum Genet 67: 82 - 91

Berthon P, Valeri A, Cohen-Akenine A, Drelon E, Paiss T, Wöhr G, Latil A, Millasseau P, Mellah I, Cohen N, Blanche H, Bellane-Chantelot C, Demenais F, Teillac P, Le Duc A, de Petriconi R, Hautmann R, Chumakov I, Bachner L, Maitland NJ, Lidereau R, Vogel W, Fournier G, Mangin P, Cohen D, Cussenot O (1998) Predisposing gene for early-onset prostate cancer, localized on chromosome 1q42.2-43. Am J Hum Genet 62: $1416-1424$

Bratt O (2000) Hereditary prostate cancer. Br J Urol Int 85: 588-598
Bratt O (2002) Hereditary prostate cancer: clinical aspects. J Urol 168: 906-913

Carpten J, Nupponen N, Isaacs S, Robbins C, Xu J, Faruque M, Moses T, Ewing C, Gillanders E, Hu P, Bujnovszky P, Makalowska I, Baffoe-Bonnie A, Faith D, Smith J, Stephan D, Wiley K, Brownstein D, Gildea D, Kelly B, Jenkins R, Hostetter G, Matikainen M, Schleutker J, Klinger K, Connors T, Xiang Y, Wang Z, De Marzo A, Papadopoulos N, Kallioniemi O-P, Burk R, Meyers D, Grönberg H, Meltzer P, Silverman R, Bailey-Wilson J, Walsh P, Isaacs W, Trent J (2002) Germline mutations in the ribonuclease L gene in families showing linkage with HPC1. Nat Genet 30: $181-184$ 
Carter BS, Beaty TH, Steinberg GD, Childs B, Walsh PC (1992) Mendelian inheritance of familial prostate cancer. Proc Natl Acad Sci USA 89: $3367-3371$

Carter BS, Bova GS, Beaty TH, Steinberg GD, Childs B, Isaacs WB, Walsh PC (1993) Hereditary prostate cancer: epidemiologic and clinical features. J Urol 150: $797-802$

Casey G, Neville PJ, Plummer SJ, Xiang Y, Krumroy LM, Klein EA, Catalona WJ, Nupponen N, Carpten JD, Trent JM, Silverman RH, Witte JS (2002) RNASEL Arg462Gln variant is implicated in up to $13 \%$ of prostate cancer cases. Nat Genet 32: $581-583$

Castelli J, Wood KA, Youle RJ (1998) The 2-5A system in viral infection and apoptosis. Biomed Pharmacother 52: 386-390

Gibbs M, Stanford JL, McIndoe TA, Jarvik GP, Kolb S, Goode EL, Chakrabarti L, Schuster EF, Buckley VA, Miller EL, Brandzel S, Li S Hood L, Ostrander EA (1999) Evidence for a rare prostate cancersusceptibility locus at chromosome 1p36. Am J Hum Genet 64: 776-787

Hassel BA, Zhou A, Sotomayor C, Maran A, Silverman RH (1993) A dominant negative mutant of 2-5A-dependent RNasel suppresses antiproliferative and antiviral effects of interferon. EMBO J 12: 3297 3304

Nakata S, Sato J, Ohtake N, Yamanaka H (1996) Regional and chronological differences of urogenital cancer death in Japan. Jpn J Urol 87: 1313-1320

Ohtake N, Hatori M, Yamanaka H, Nakata S, Sada M, Tsuji T (1998) Familial prostate cancer in Japan. Int J Urol 5: 138-145

Ohtake N, Nakata S, Fukabori Y, Suzuki K, Yamanaka H (2002) Update of familial prostate cancer in Japan (in Japanese). Nihon Rinsho 60: 469473

Rennert H, Vercovich D, Hubert A, Abeliovich D, Rozovsky U, Bar-Shira A, Soloviov S, Shreiber L, Matzkin H, Rennert G, Kadouri U, Peretz T, Yaron Y, Orr-Urtreger A (2002) A novel founder mutation in the RNASEL gene, 471 delAAAG, is associated with prostate cancer in Ashkenazi Jews. Am J Hum Genet 71: $981-984$

Rökman A, Ikonen T, Seppälä EH, Nupponen N, Autio V, Mononen N, Bailey-Wilson J, Trent J, Carpten J, Matikainen MP, Koivisto PA,
Tammela TLJ, Kallioniemi O-P, Schleutker J (2002) Germline alterations of the RNASEL gene, a candidate HPC1 gene at 1q25, in patients and families with prostate cancer. Am J Hum Genet 70: 1299-1304

Smith JR, Freije D, Carpten JD, Grönberg H, Xu J, Isaacs SD, Brownstein MJ, Bova G.S, Guo H, Bujnovszky P, Nusskern DR, Damberg J-E, Bergh A, Emanuelsson M, Kallioniemi O-P, Walker-Daniels J, Bailey-Wilson JE Beaty TH, Meyers DA, Walsh PC, Collins FS, Trent JM, Isaacs WB (1996) A genome wide search reveals a major susceptibility locus for porstate cancer on chromosome 1. Science (Washington DC) 274: 1371-1374

Tavtigian SV, Simard J, Teng DHF, Abtin V, Baumgard M, Beck A, Camp NJ, Carillo AR, Chen Y, Dayananth P, Desrochers M, Dumont M, Farnham JM, Frank D, Frye C, Ghaffari S, Gupte JS, Hu R, Iliev D, Janecki T, Kort EN, Laity KE, Leavitt A, Leblanc G, McArthur-Morrison J, Pederson A, Penn B, Peterson KT, Reid J, Richards S, Schroeder M, Smith R, Snyder SC, Swedlund B, Swensen J Thomas A, Tranchant M, Woodland A-M, Labrie F, Skolnick MH, Neuhausen S, Rommens J, Cannon-Albright LA (2001) A candidate prostate cancer susceptibility gene at chromosome 17p. Nat Genet 27: 172-180

Wang J, McDonnell SK, Elkins DA, Slager SL, Christensen E, Marks AF, Cunningham JM, Peterson BJ, Jacobsen SJ, Cerhan JR, Blute ML, Schaid DJ, Thibodeau SN (2002) Analysis of the RNASEL gene in familial and sporadic prostate cancer. Am J Hum Genet 71: 116-123

Xu J, Mayers D, Freije D, Isaacs S, Wiley K, Nusskern D, Ewing C, Wilkens E, Bujnovszky P, Bova GS, Walsh P, Isaacs W, Schleutker J, Matikainen M, Tammela T, Visakorpi T, Kallioniemi O-P, Berry R, Schaid D, French A, McDonnell S, Schroeder J, Blute M, Thibodeau S, Grönberg $H$, Emanuelsson M, Damber J-E, Bergh A, Jonsson B-A, Smith J, BaileyWilson J, Carpten J, Stephan D, Gillanders E, Amundson I, Kainu T, Freas-Lutz D, Baffoe-Bonnie A, Van Aucken A, Sood R, Collins F, Brownstein M, Trent J (1998) Evidence for a prostate cancer susceptibility locus on the X chromosome. Nat Genet 20: 175-179

Zhou A, Hassel BA, Silverman RH (1993) Expression cloning of 2-5Adependent RNAase: a uniquely regulated mediator of interferon action. Cell 72: $753-765$ 